\section{La Declaración y el Proceso de Bolonia deben reconsiderarse}

Andrzej Wojtczak

\section{The Bologna Declaration and Process must be reconsidered}

Lo que se conoce como 'Proceso de Bolonia', plasmado en la llamada 'Declaración de Bolonia', surgió de una serie de Conferencias de Ministros de Educación Superior Europeos que centraron su interés en diferentes aspectos como la mejora de la transparencia y la calidad de la enseñanza universitaria. Actualmente son 46 los países europeos firmantes de la Declaración de Bolonia $\mathrm{y}$ aunque muchos han acogido con satisfacción este proceso como un hecho positivo para la educación superior, otros se han centrado sobre lo que consideraban peligros potenciales.

Para los educadores médicos, el Proceso de Bolonia se ha visto sobre todo como un intento de dividir los estudios de pregrado de medicina en dos ciclos: el primero, que comprendería los tres primeros años y que conduciría a un grado, y el segundo, también de tres años, que llevaría al título de máster. Muchos educadores médicos han considerado desde el principio que dicha división no tenía mucho sentido en el caso de los estudios de medicina y que comportaba un peligro para la integración de la enseñanza preclínica y clínica. Por ello, y hasta la actualidad, con la excepción de unos pocos países europeos que han implementado el sistema de dos ciclos, la mayoría de las facultades de medicina, con el apoyo de sus gobiernos, han decidido no adoptar esta división que se justifica plenamente en la mayoría de los demás estudios universitarios. La consecuencia de todo ello es que este problema ha eclipsado otros aspectos importantes del Proceso de Bolonia y sus objetivos clave. Estos objetivos se relacionan con temas tan importantes como el reconocimiento general de las titula-
What is known as the 'Bologna Process', which is materialised in the so-called 'Bologna Declaration', arose from a series of Conferences of European Ministers responsible for Higher Education that focused their attention on a number of different aspects, such as enhancing the transparency and the quality of university education. To date, 46 European countries have signed the Bologna Declaration and although many have welcomed this process as something positive for higher education, others have concentrated on what they see as its potential dangers.

For those working in medical education, the Bologna Process has been seen above all as an attempt to divide undergraduate medical studies up into two cycles: one would be the first three years of study leading to a degree and the other would also last three years and would lead to a master's degree. Right from the outset, many of those who teach medicine have considered that such a division makes little sense in the case of medical studies and also endangers the integration of preclinical and clinical education. Thus, to date, with the exception of just a few European countries that have implemented the two-cycle system, most faculties of medicine, with the support of their governments, have decided not to adopt this division which is fully justified in most other university studies. The upshot of all this is that it has become an issue that has eclipsed other important aspects of the Bologna Process and its key goals. These goals have to do with such important topics as the general recognition of qualifications throughout the whole of Europe, student-centred learning, cooperation to ensure quality, fostering
Exdirector del International Institute for Medical Education (IME).

Expresidente de la Association for Medical Education in Europe (AMEE)

E-mail wojtczak@cmkp.edu.pl 
ciones en toda Europa, el aprendizaje centrado en el estudiante, la cooperación para asegurar la calidad, la promoción de la movilidad de estudiantes y profesores y la internalización de los estudios que merecen atención y apoyo.

Sin embargo, un hecho todavía más importante y uno de sus puntos fuertes es la naturaleza dinámica del Proceso de Bolonia, y por tanto, su continua evolución y ampliación. Si se utiliza adecuadamente, puede servir como un catalizador de los cambios que la educación médica necesita y ayudar a resolver muchos problemas que pueden ser muy beneficiosos para los educadores médicos. Por lo tanto, la educación médica y los educadores médicos deben participar activamente en muchos aspectos del Proceso de Bolonia. La revitalización de los elementos importantes de este proceso entre los educadores médicos llega en el momento adecuado, ya que necesitamos más que nunca de la cooperación internacional y la orientación, la movilidad de los estudiantes y del personal, y la cooperación entre los educadores médicos y las facultades de medicina.

Lo que precisamos es un sistema transparente que permita a los países comprender los otros sistemas educativos europeos y las materias o asignaturas específicas de otros estudios. El objetivo principal no es la conformidad y un currículo uniforme, sino armonizar y aclarar las complejidades de sistemas educativos diferentes. Es muy necesaria la movilidad del profesorado, de los estudiantes y graduados, lo cual constituye otro de los elementos nucleares del Proceso de Bolonia y que pusieron de relieve los ministros de educación superior participantes en la $\mathrm{V}$ Conferencia Ministerial de Bolonia en el 2007. Para lograr este ambicioso objetivo se han ido implementando de forma gradual varios instrumentos. Estos incluyen los créditos ECTS, un marco de tres ciclos con resultados de aprendizaje bien especificados para cada uno de ellos y las cualificaciones requeridas. Sin embargo, todavía queda mucho por hacer en este campo, a pesar de los avances en la superación de las trabas burocráticas existentes en los distintos países. Unas herramientas que facilitan el reconocimiento de las cualificaciones son los resultados de aprendizaje que se incluyen en las descripciones de los diferentes módulos que conforman cada paquete de créditos ECTS. Supone un paso importante hacia el logro de una mayor claridad y calidad en the mobility of students and teaching staff, and the internalisation of studies that deserve attention and backing.

Yet, an even more important fact and one of its strong points is the dynamic nature of the Bologna Process and, hence, its ongoing evolution and expansion. If used appropriately, it can serve as a catalyst for the changes that medical education needs and help find solutions to many problems that can be very beneficial for those involved in medical teaching. Thus, medical education and medical teachers must participate actively in many aspects of the Bologna Process. The revitalisation of the important elements of this process among medical teachers comes at just the right time because now, more than ever before, we need international cooperation and guidance, the mobility of students and staff, and cooperation between medical teachers and medical schools.

What is needed is a transparent system that allows countries to understand the other European educational systems and the specific subjects of other courses of study. The main aim is not conformity and a uniform curriculum, but instead to harmonise and smooth out the complexities of different educational systems. The mobility of teaching staff, students and graduates is crucial and is another of the core elements of the Bologna Process that were highlighted by the ministers responsible for higher education who attended the 5th Ministerial Conference in Bologna in 2007. With the aim of accomplishing this ambitious goal, several instruments have gradually been implemented. These tools include ECTS credits, a framework of three cycles with well-specified learning outcomes for each of them and the required qualifications. Nevertheless, there is still a lot of work to be done in this field, despite the advances that have been made to overcome the bureaucratic obstacles that exist in some countries. Some tools that make recognition of qualifications easier are the learning outcomes that are included in the descriptions of the different modules that make up each packet of ECTS credits. This is an important step towards achieving greater clarity and quality in teaching, with greater emphasis placed on student-centred learning.

It is also important to underline the fact that the Bologna Process must be seen as a commitment to improve the quality of teaching by shifting the focus to student-centred learning and to the success of students' individual learning. There is a need to implement curricula oriented towards clearly 
la enseñanza, poniendo un mayor énfasis en el aprendizaje centrado en el estudiante.

Es importante destacar también que el Proceso de Bolonia debe verse como un compromiso para mejorar la calidad de la enseñanza desplazando el punto de mira hacia el aprendizaje centrado en el estudiante y en el éxito del aprendizaje individual de los estudiantes. Se requiere implementar currículos orientados a resultados de aprendizaje claramente definidos, lo que ha sido fijado en el 'Proyecto Tuning. El proyecto pretende la adopción de un sistema de titulaciones fácilmente comprensible y comparable mediante la identificación de puntos de referencia para las competencias generales y específicas.

Cumming y Ross [1] especificaron los resultados de aprendizaje (competencias) a alcanzar en la educación médica de grado en Europa como parte del desarrollo del denominado proyecto Medine-1. Es importante considerar que las competencias se describen como puntos de referencia para el diseño curricular y la evaluación, y no como un corsé rígido. Permiten flexibilidad y autonomía en la elaboración de planes de estudio. Al mismo tiempo, introducen un lenguaje común para describir lo que los programas pretenden. Por ello, las tasas de movilidad se sugirieron como un criterio para determinar el éxito de las reformas de Bolonia. Bolonia pretende crear oportunidades para el crecimiento personal y desarrollo de la cooperación internacional entre individuos e instituciones, necesarias para mejorar la calidad de la educación superior y la investigación.

Otra área sujeta a discusión es el reconocimiento de las calificaciones. El objetivo es posibilitar que los alumnos utilicen sus calificaciones obtenidas en un sistema educativo en otro sistema educativo, o en otro país, sin perder su valor real. La concesión de títulos conjuntos deberá considerarse en un futuro próximo. Además, una línea de actuación muy importante del Proceso de Bolonia es la garantía de calidad. Se refiere a todas las políticas, los procesos de evaluación y las acciones destinadas a garantizar que las instituciones, los programas y las calificaciones reúnan y mantengan determinados estándares de calidad educativa, académica y de infraestructura. Su objetivo es ayudar a establecer una cultura de calidad en las universidades de una manera sostenible y duradera, contribuyendo al mismo tiempo a la autonomía institucional y a la responsabilidad social. La garantía de calidad ha de verse como parte del defined learning outcomes, something which has been set out in the 'Tuning Project'. The aim of the project is to adopt a system of qualifications that is easy to understand and compare by identifying points of reference for general and specific skills.

Cumming and Ross [1] specified the learning outcomes (competencies) to be reached in undergraduate medical education in Europe as part of the development of the so-called Medine-1 project. It is important to bear in mind that the competencies are described as points of reference for the sake of curricular design and assessment, and not as a rigid set of rules. They allow curricula to be developed in a flexible autonomous manner. At the same time, they introduce a common language for describing the targets of the different curricula. Mobility rates have therefore been suggested as a criterion for determining the success of the Bologna reforms. Bologna aims to create opportunities for personal growth and the development of international cooperation among individuals and institutions, which are necessary to improve the quality of higher education and research.

Another area that is under discussion is the recognition of qualifications. The objective is to make it possible for students to use the qualifications they obtain in one educational system in another educational system, or in another country, without them losing their real value. Joint degrees are something that should be considered in the near future. Furthermore, one very important line of action in the Bologna Process is quality assurance. This refers to all the policies, assessment processes and actions geared towards ensuring that institutions, programmes and qualifications fulfil and maintain certain standards as regards educational, academic and infrastructure quality. Its objective is to help establish a culture of quality in universities in a sustainable, long-lasting manner, while at the same time contributing to institutional autonomy and social responsibility. Quality assurance must be seen as part of the ongoing process of development and improvement of higher education and is a fundamental requisite for the mobility of teaching staff. The objective of the Bologna Process is to foster European cooperation in quality assurance so as to be able to develop comparable criteria and methodologies.

Very recently, the Conference of Ministers drew attention to the urgent need to improve students capacity for permanent lifelong learning as a fundamental element of the Bologna Process, which 
desarrollo continuo y de la mejora de la educación superior y es un requisito básico para la movilidad del profesorado. El Proceso de Bolonia tiene como objetivo fomentar la cooperación europea en la garantía de calidad con el fin de desarrollar criterios y metodologías comparables.

Muy recientemente, la Conferencia de Ministros ha llamado la atención sobre la urgente necesidad de mejorar en los estudiantes la capacidad de aprender de forma permanente a lo largo de vida como elemento fundamental del Proceso de Bolonia, que es mucho más que una simple reforma estructural. Hay una creciente toma de conciencia de la necesidad de integrar la educación permanente en la educación superior. Este desarrollo continuo de la educación médica constituye un requisito para satisfacer las necesidades del siglo xxi. Puede ser un catalizador para un nuevo examen de los enfoques actuales de la educación médica en términos de planificación curricular, de resultados del aprendizaje, de los métodos de enseñanza y aprendizaje y de la evaluación, tan necesario por lo que respecta a las perspectivas internacionales de la educación médica.

Por último, es necesario subrayar que no hay suficiente conciencia estratégica entre el personal de las facultades de medicina sobre la importancia del Proceso de Bolonia en el desarrollo de la política educativa europea, que podría ser una poderosa fuerza motriz en la mejora de la calidad de la educación médica moderna. Por lo tanto, es fundamental que la información sobre los objetivos del Proceso de Bolonia llegue de forma más intensa y generalizada al oído de todos los miembros de las facultades de medicina, estimulando su participación activa. Por ello resulta clave que todo lo que implica la Declaración de Bolonia, su importancia y el proceso en su conjunto, se revise de nuevo y se reconsideren los aspectos importantes con el fin de que puedan implementarse lo más rápidamente posible. is a lot more than just a simple structural reform. Awareness of the need to integrate permanent education within higher education is growing. This continuous development of medical education is a necessary requirement in order to satisfy the needs of the 21st century. It may act as a catalyst that triggers a new examination of the current approaches employed in medical education in terms of curricula planning, learning outcomes, teaching and learning methods, and assessment, which is so necessary as regards the international perspectives of medical education.

Finally, it should be emphasised that there is not enough strategic awareness among the staff of medical schools of the importance of the Bologna Process in the development of the European educational policy, which could be a powerful driving force in improving the quality of today's medical education. Information about the goals of the Bologna Process must therefore reach the ears of all the members of medical schools in a more intensive and generalised way, thereby stimulating their active participation. It is thus essential that everything the stems from the Bologna Declaration, its importance and the whole process, should be reviewed again and the most significant aspects reconsidered so that they can be implemented as quickly as possible.

\section{Bibliografía / References}

1. Cumming A, Ross M, Steering Group and Task Force of the MEDINE Thematic Network. The Tuning Project for Medicine-learning outcomes for undergraduate medical education in Europe. Med Teach 2007; 29: 636-41. 